УДК 343.36;343.33:[341.4](477)

DOI https://doi.org/10.32849/2663-5313/2019.12.53

\title{
Руслан Волинещь,
}

докт. юрид. наук, дочент,

доцент кафедри кримінального права та кримінології

Київського начіонального університету імені Тараса Шевченка

\section{ДО ПИТАННЯ РАТИФІКАЦІЇ РИМСЬКОГО СТАТУТУ МІЖНАРОДНОГО КРИМІНАЛЬНОГО СУДУ}

Стаття присвячена питанням щодо необхідості та дочільності внесення окремих змін в начіональне законодавство у разі ратифікаиіі Римського статуту Міжнародного кримінального суду. Проаналізовано та підтримано позицію, висловлену в юридичній літературі, згідно з якою ратифікація Римського статуту потребує комплексних змін Особливої частини Кримінального кодексу України, до якої необхідно внести низку поправок шодо визначення понять злочинів, які передбачені иим Статутом (злочини геночиду, злочини проти людяності, воєнні злочини й злочини агресіі), та закріплення їх вичерпного переліку. Також у статті звернуто увагу на один із аспектів на користь чієї позииії. Так, у частині четвертій статті 10 Кримінального кодексу України зазначено, що виконання в Україні вироку іноземного суду чи міжнародної судової установи можливо, якщо діяння, внаслідок вчинення якого було ухвалено вирок, згідно з иим Кодексом визнається злочином або було б злочином у разі його вчинення на території України. Це означає, що якщо якийсь із злочинів, передбачених Римським статутом Міжнародного кримінального суду, не визнається кримінальним правопорушенням, передбаченим чинним Кримінальним кодексом України, то вирок, постановленийза наслідками його розгляду, не зможе бути виконаний на території України, навіть якщо Міжнародний кримінальний суд прийме рішення щодо засудження громадянина Украйни. В умовах збройного конфлікту, який триває на сході України, гармонізачія кримінального законодавства з відповідними положеннями Римського статуту Міжнародного кримінального суду набуває особливої ваги.

Також у статті проаналізовано законопроекти, спрямовані на гармонізачію начіонального законодавства з положеннями міжнародного гуманітарного права, в тому числі з положеннями Римського статуту Міжнародного кримінального суду. За результатами такого аналізу було зроблено висновок, що иі законопроекти не мають комплексного характеру та не регулюватимуть

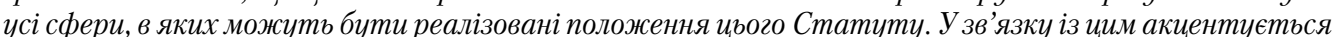
увага на тому, що ратифікачія Римського статуту Міжнародного кримінального суду однозначно має носити комплексний характер та супроводжуватися відповідними змінами до кримінального, кримінального прочесуального та кримінально-виконавчого законодавства, які було напрацьовано за ией час науковиямми, представниками громадських організачій та суб'єктами законодавчої ініиіативи.

Ключові слова: міжнародне гуманітарне право, Римський статут Міжнародного кримінального суду; міжнародні злочини, злочини геноциду, злочини проти людяності, воєнні злочини, злочини агресії.

Постановка проблеми. В Україні вже досить довгий час триває дискусія щодо ратифікації Римського статуту Міжнародного кримінального суду (далі - Римський статут). Слід зазначити, що Україна брала активну участь у підготовці Римського статуту та підписала його ще 20 січня 2000 року, проте й досі не ратифікувала. Аналіз юридичної літератури та преси вказує на те, що частина правників, державних діячів, політиків, правоохоронців, адвокатів, журналістів, представників неурядових організацій активно обстоюють позицію щодо необхідності підписання Римського статуту [3, с. $123-128 ; 1$, с. $79-96 ; 4 ; 13 ; 7 ; 9]$, водночас інша частина застерігає проти такої ратифікації, вказуючи на ряд негативних наслідків, що можуть спіткати Україну в разі необдуманої ратифікації [6; 8; 14].

Змістовний та комплексний підхід до питань, пов'язаних 3 ратифікацією Римського статуту, висвітлений $\mathrm{y}$ роботах, зокрема, таких науковців, як Н.А. Боднар, М.М. Гнатовський, О.В. Задорожній, У.3. Коруц, П.Д. Пилипенко, В.П. Попович, С.П. Кучевська, О.В. Сенаторова, В.С. Скомороха.

У цій статті не розглядатиметься питання щодо доцільності або недоцільності ратифікації Римського статуту. 
Метою статті є розгляд питання щодо необхідності та доцільності внесення окремих змін у національне законодавство у разі ратифікації Римського статуту.

Виклад основного матеріалу. Відповідно до ч. 7 ст. 9 Закону України «Про міжнародні договори України», якщо на ратифікацію подається міжнародний договір, виконання якого потребує прийняття нових або внесення змін до чинних законів України, проекти таких законів подаються на розгляд Верховної Ради України разом із проектом закону про ратифікацію і приймаються одночасно. Отже, перед тим, як ратифікувати той чи інший міжнародно-правовий акт, необхідно провести аналіз національного законодавства на предмет тих змін, яких воно потребуватиме у разі прийняття рішення про ратифікацію.

В юридичній літературі зазначено, що ратифікація Римського статуту потребує комплексних змін Особливої частини Кримінального кодексу України (далі - КК), до якої необхідно внести низку поправок щодо визначення понять злочинів, які передбачені цим Статутом (злочини геноциду, злочини проти людяності, воєнні злочини й злочини агресіі), та закріплення їх вичерпного переліку. Наприклад, С.П. Кучевська вказує, що незважаючи на те, що норми Римського статуту містять ознаки самовиконуваних міжнародних норм, основною умовою набуття Статутом чинності щодо конкретної держави є приєднання до нього та приведення національного законодавства у відповідність до Статуту для забезпечення ефективного виконання покладених МКС функцій [5, с. 23].

У свою чергу В.П. Попович зазначає, якщо Україна ратифікує Римський статут, необхідно буде у КК ввести значну кількість нових складів злочинів, що підпадають під юрисдикцію Міжнародного кримінального суду, а також внести зміни в чинні склади злочинів (зокрема, обсяг поняття геноциду за Римським статутом не відповідає обсягу цього поняття, сформульованого в ст. 442 КК) [10, с. 68].

Виходячи 3 класифікації, закріпленої в Римському статуті, науковець виділяе в чинному КК такі серйозні порушення норм міжнародного гуманітарного права: 1) злочин геноциду, як один із найнебезпечніших злочинів проти людяності (ст. 442); 2) воєнні злочини: незаконне використання символіки Червоного Хреста, Червоного Півмісяця, Червоного Кристала та зловживання ними (ст. 435); порушення законів та звичаїв війни (ст. 438); застосування зброї масового знищення (ст. 439); розроблення, виробництво, придбання, зберігання, збут, транспортування зброї масового знищення (ст. 440); 3) злочини агресії: пропаганда війни (ст. 436); планування, підготовка, розв'язування та ведення агресивної війни (ст. 437). Однак у розділі XX КК не встановлено кримінальну відповідальність за злочини проти людяності, хоча цього вимагає значна кількість міжнародних актів, зокрема і Римський статут. Крім того, ряд із вищезазначених злочинів також підлягають відповідним змінам [10, с. 177-181].

Отже, в науковій літературі було констатовано, що ратифікація Римського статуту зумовлює внесення відповідних змін до кримінального законодавства України, і на цій підставі було запропоновано відповідні зміни [5, с. 190-198; 10, с. 177-181].

Поділяючи думку, згідно з якою Ратифікація римського статуту має неодмінно супроводжуватись відповідними змінами кримінального законодавства України, хочу звернути увагу на один із аспектів на користь цієї позиції. Так, у ч. 4 ст. 10 КК зазначено, що виконання в Україні вироку іноземного суду чи міжнародної судової установи можливо, якщо діяння, внаслідок вчинення якого було ухвалено вирок, згідно з цим Кодексом визнається злочином або було б злочином у разі його вчинення на території України. Це означає, що якщо якийсь із злочинів, передбачених Римським статутом, не визнається кримінальним правопорушенням, передбаченим чинним КК, то вирок, постановлений за наслідками його розгляду, не зможе бути виконаний на території України, навіть якщо Міжнародний кримінальний суд прийме рішення щодо засудження громадянина України. В умовах збройного конфлікту, який триває на сході України, гармонізація кримінального законодавства з відповідними положеннями Римського статуту набуває особливої ваги.

Необхідність внесення відповідних змін у кримінальне законодавство України було визначено як один із напрямів у Плані заходів з реалізації Національної стратегії у сфері прав людини на період до 2020 року. Так, було визначено, що одним із заходів, спрямованих на додержання норм міжнародного права для захисту життя мирного населення на тимчасово окупованій території України, $€$ проведення аналізу відповідності норм міжнародного гуманітарного права та кримінального законодавства України

3 метою виявлення прогалин та невідповідності (наприклад, щодо визначення воєнних злочинів). На основі результатів зазначеного аналізу мав бути розроблений законопроект щодо внесення змін до КК 
та в разі потреби розроблені зміни до інших нормативно-правових актів, а також внесено подання до Верховної Ради України з метою гармонізації з нормами міжнародного гуманітарного права (зокрема, щодо визначення воєнних злочинів) [15]

У 2016 році за ініціативою Центру Громадських Свобод експертами було розроблено та презентовано проект Закону «Про внесення змін до Кримінального кодексу України щодо забезпечення його гармонізації до положень Римського статуту Міжнародного кримінального суду» [12], який передбачає ряд змін і доповнень до КК, серед яких запропоновано: визначення понять злочинів «Обернення у рабство», «Злочини проти людяності», «Воєнні злочини проти осіб», «Воєнні злочини проти правосуддя», «Воєнні злочини майнового характеру», «Воєнні злочини проти гуманітарних операцій та використання символів», «Воєнні злочини, які полягають у застосуванні заборонених методів ведення війни», «Воєнні злочини, які полягають у застосуванні заборонених засобів ведення війни»; уточнено поняття злочинів геноциду та повністю змінено ст. 437 щодо злочину агресії. Крім того, вказаним законопроектом було запропоновано внести відповідні зміни до Кримінального процесуального кодексу України (далі - КПК), Закону України «Про застосування амністії в Україні», до Кримінально-виконавчого кодексу України (далі - КВК), до Закону України «Про пробацію» [1, с. 85-86]. Щоправда, цей законопроект так і не було зареєстровано у Верховній Раді України.

Наступна спроба врегулювати зазначене питання на законодавчому рівні була реалізована у проекті Закону України «Про внесення змін до деяких законодавчих актів України щодо забезпечення гармонізації кримінального законодавства 3 положеннями міжнародного права», поданому до Верховної Ради України VIII скликання [11]. На відміну від попереднього, цей законопроект прийнято у першому читанні, а тому згідно з Регламентом Верховної Ради він може бути поданий до другого читання.

Положення цього проекту Закону утворюють декілька змістових блоків: 1) положення щодо автономної регламентації кримінальної відповідальності за злочини агресії, геноциду, злочини проти людяності та воєнні злочини; 2) положення, які передбачають окремі зміни структури Особливої частини КК у зв'язку 3 автономною регламентацією кримінальної відповідальності за злочини агресії, геноциду, злочини проти людяності та воєнні злочини; 3) положення, спрямовані на вдосконалення правового режиму кримінальної відповідальності за катування; 4) зміни до КПК щодо уточнення підслідності відповідної категорії злочинів та передбачення можливості спеціального досудового розслідування та судового розгляду цих злочинів.

Проаналізувавши положення цього законопроекту, Головне науково-експертне управління Апарату Верховної Ради України висловило ряд слушних зауважень [2], до яких можна додати ще декілька зауважень, які зумовлені тим, що цей законопроект, виходячи з його назви та пояснювальної записки, не розроблявся виключно для гармонізації національного законодавства 3 положеннями Римського статуту, а його прийняття не зумовлено ратифікацією Статуту.

По-перше, у законопроекті пропонується передбачити у ст. 8-1 КК правило, згідно 3 яким, якщо вирішуватиметься питання щодо притягнення до відповідальності за агресію (ст. 437 КК), злочини проти людяності (ст. 437-1 КК), воєнні злочини (статті 438-438-6 КК) або геноцид (ст. 442 КК), особи підлягатимуть кримінальній відповідальності на підставі КК незалежно від місця вчинення злочину. При цьому не враховано положення ст. 21 Римського статуту, згідно з якими Міжнародний кримінальний суд застосовує: а) по-перше, цей Статут, елементи злочинів та свої Правила процедури і доказування; b) по-друге, у відповідних випадках, міжнародні договори, що застосовуються, принципи і норми міжнародного права, включаючи загальновизнані принципи міжнародного права збройних конфліктів; с) якщо це неможливо, Суд застосовує загальні принципи права, взяті ним із національних законів правових систем світу, включаючи, відповідно, національні закони держав, які за звичайних обставин здійснювали би юрисдикцію щодо даного злочину за умови, що ці принципи не $€$ несумісними 3 цим Статутом та 3 міжнародним правом і міжнародно визнаними нормами і стандартами. Тобто насамперед Міжнародний кримінальний суд застосовує Римський статут та інші міжнародно-правові акти i, лише якщо це не можливо, відповідні положення національного законодавства. Тобто ст. 8-1 КК створює колізію зі ст. 21 Римського статуту.

По-друге, у законопроекті відсутні відповідні зміни до КПК та КВК, які регламентували би порядок взаємодії Міжнародного кримінального суду з національними правоохоронними органами та судами у питаннях здійснення розслідування, судового розгляду та виконання рішень цього Суду. Так, наприклад, звернення до положень КПК 
дозволяе зробити висновок, що в ньому належним чином регламентується порядок виконання рішень такої міжнародної інституції, як Європейський Суд з прав людини. При цьому аналіз розділу IX «Міжнародне співробітництво під час кримінального провадження» КПК дозволяє зробити висновок, що цим Розділом лише регулюються питання міжнародного співробітництва з іншими країнами, а не міжнародними судовими органами.

У цьому контексті хотілося б звернути увагу на проект Закону України «Про ратифікацію Римського статуту Міжнародного кримінального суду та поправок до нього» та проект Закону України «Про внесення змін до деяких законодавчих актів України у зв'язку з ратифікацією Римського статуту Міжнародного кримінального суду», які нині розроблені Міністерством юстиції України.

При цьому останнім із зазначених законопроектів пропонується доповнити КПК розділом IX-2 «Особливості співробітництва 3 Міжнародним кримінальним судом». Відповідно до ч. 1 ст. 623 цього Розділу «Виконання Міжнародним кримінальним судом функцій на території України» КПК, прокурор Міжнародного кримінального суду на підставі та на виконання прохання Міжнародного кримінального суду може самостійно проводити процесуальні дії на території України, за винятком процесуальних дій, виконання яких в Україні здійснюється за погодженням із прокурором або з дозволу слідчого судді, суду. Зазначені положення не повною мірою узгоджуються з вимогами пп. «д» п. 3 ст. 57 Римського статуту, згідно 3 якими поряд зі своїми іншими функціями за цим Статутом Палата попереднього провадження може, зокрема, надавати прокуророві дозвіл на прийняття спеціальних заходів, що належать до проведення розслідування в межах території держави-учасниці, без отримання з боку цієї держави згоди на співробітництво відповідно до частини дев'ятої «Міжнародне співробітництво і судова допомога», якщо, взявши до уваги (оскільки це можливо) думки відповідної держави, Палата попереднього провадження стосовно даного випадку встановила, що ця держава явно не здатна виконати прохання про співробітництво з причини відсутності будь-якого органу або елемента його судової системи, наділеного повноваженнями, необхідними для виконання прохання про співпрацю відповідно до частини 9 Римського статуту.

Незважаючи на окремі недоліки, беззаперечно, наявність таких змін $є$ перевагою порівняно з попередніми законопроектами, однак викликає запитання той факт, що цим законопроектом не пропонується внесення змін ані до КК, ані до КВК, і це при тому, що необхідність таких змін як обгрунтована у юридичній літературі, так і обговорена в експертному середовищі. Більше того, це $\epsilon$ ігноруванням вже згадуваних положень ч. 7 ст. 9 Закону України «Про міжнародні договори України». У зв'язку із цим зміни, обумовлені ратифікацією Римського статуту, повинні мати комплексний системний характер, тим більше що напрацювання у цьому напрямі здійснюються досить тривалий час.

\section{Висновки}

Натепер в Україні немає єдності думок щодо необхідності ратифікації Римського статуту. Такий стан справ певною мірою не сприяє однозначному усвідомленню того факту, що національне законодавство потребує приведення у відповідність до положень міжнародного гуманітарного права. При цьому такі зміни мають відбутись незалежно від прийняття рішення про ратифікацію Римського статуту. Водночас ратифікація Римського статуту однозначно повинна мати комплексний характер та супроводжуватись відповідними змінами до кримінального, кримінального процесуального та кримінально-виконавчого законодавства, які було напрацьовано за цей час науковцями, представниками громадських організацій та суб’єктами законодавчої ініціативи.

\section{Список використаних джерел:}

1. Боднар Н.А. Проблема ратифікації Римського статуту Міжнародного кримінального суду в світлі європейського вибору України. Журнал європейського і порівняльного права. 2018. № 8. С. 79-96.

2. Висновок Головного науково-експертного управління Апарату Верховної Ради України на проект Закону України «Про внесення змін до деяких законодавчих актів України щодо забезпечення гармонізації кримінального законодавства 3 положеннями міжнародного права» (реєстр. № 9438 від 20 грудня 2018 року) / Верховна Рада України. URL: http://w1.c1.rada.gov.ua/ pls/zweb2/webproc4_1?pf3511=65266 (дата звернення: 02.11.2019).

3. Коруц У. Правова природа та сутнісне значення принципу компліментарності Міжнародного кримінального суду і його місце в системі кримінальної юстиції держави. Visegrad Journal on Human Rights. 2016. № 4/1. P. 123-128.

4. Корыневич А. Почему Украина должна ратифицировать Римский статут Международного уголовного суда. Українська правда. URL https://www.pravda.com.ua/rus/columns/2019/08/20/ 7224001/ (дата звернення: 10.11.2019).

5. Кучевська С. П. Проблеми гармонізації законодавства України про кримінальну відпо- 
відальність та Статуту Міжнародного кримінального суду : дис. ... канд. юрид. наук: 12.00.08. Львів, 2009. 338 c.

6. Луценко I. Ратифікація Римського статуту несе ризики для українських військовослужбовців. LB.UA. URL: https://ukr.lb.ua/ news/2019/08/16/434855_ratifikatsiya_rimskogo_ statutu_nese.html (дата звернення: 10.11.2019).

7. Мамедов Г. Ратифікація Римського статуту дасть змогу Україні повною мірою використати інструментарій МКС для обстоювання своїх прав. Інтерфакс-Україна. URL: https:// ua.interfax.com.ua/news/general/607548.html (дала звернення: 20.10.2019)

8. Обговорили ратифікацію Римського статуту. Голос Украӥни. URL: http://www.golos.com.ua/ article/323139 (дата звернення: 25.11.2019).

9. Печончик Т. Ратифікація Римського статуту надасть Україні більше прав. Новинарня. URL https://novynarnia.com/2019/08/16/ratifikatsiyarimskogo-statutu-nadast-ukrayini-bilshe-pravpechonchik/ (дата звернення: 15.09.2019).

10. Попович В.П. Імплементація норм міжнародного гуманітарного права у кримінальне законодавство України : дис. ... канд. юрид. наук: 12.00.08. Львів, 2010. 322 с.

11. Проект Закону України «Про внесення змін до деяких законодавчих актів України щодо забезпечення гармонізації кримінального законодавства 3 положеннями міжнародного права» (реєстр. № 9438 від 20 грудня 2018 року) / Верховна Рада Украӥни. URL: http://w1.c1.rada.gov.ua/ pls/zweb2/webproc4_1?pf3511=65266 (дата звернення: 02.11.2019).

12. Проект Закону України «Про внесення змін до Кримінального кодексу України щодо забезпечення його гармонізації 3 положеннями Римського статуту Міжнародного кримінального суду». URL: https://webcache.googleusercontent.com/ search?q=cache:XC_vCZSRzzwJ:https:// precedent.in.ua/wp-content/uploads/2016/07/ proekt-ZU-shhodo-garmonizatsiyipolozhen-KK-zpolozhennyamy-Rymskogo-Statutu-16.05.2016-1. $\mathrm{doc}+\& \mathrm{~cd}=1 \& \mathrm{hl}=\mathrm{uk} \& \mathrm{ct}=\mathrm{clnk} \& \mathrm{gl}=\mathrm{ua} . \quad$ (дата нення: 01.11.2019).

13. Ратифікація Римського статуту дозволить Україні мати не лише зобов'язання, а й права / Українська Гельсінська спілка з прав людини. URL: https://helsinki.org.ua/articles/ratyfikatsiia-rymskoho-statutu-dozvolyt-ukraini-maty-ne-lyshe-zoboviazannia-a-y-prava/ (дата звернення: 17.11.2019).

14. Римський статут: ратифікувати не можна чекати / Український інституту майбутнього. URL: https://www.uifuture.org/publications/news/ 24907-rymskyi/statut/ratyfikuvaty/nemozna/ chekaty (дата звернення: 20.11.2019).

15. Про затвердження плану дій з реалізації Національної стратегії у сфері прав людини на період до 2020 року : Розпорядження Кабінету Міністрів України від 23 листопада 2015 року № 1393-р / Верховна Рада Украіни. URL: http://zakon2.rada.gov.ua/laws/ show/1393-2015-\%D1\%80 (дата звернення: 20.11.2019).

The article deals with the necessity and expediency of introducing separate amendments to the national legislation, in case of ratification of the Rome Statute of the International Criminal Court. The position expressed in the legal literature is analyzed and supported, according to which the ratification of the Rome Statute requires comprehensive amendments to the Special Part of the Criminal Code of Ukraine, which requires a number of amendments to define the concepts of crimes envisaged by this Statute (crimes of genocide, crimes, crimes and crimes of aggression), and consolidating their exhaustive list. The article also drawes attention to one aspect in favor of this position. Thus, in part 4 of Article 10 of the Criminal Code of Ukraine it is stated that the execution in Ukraine of a sentence of a foreign court or an international judicial institution is possible if the act resulting from the execution of which the sentence was passed is recognized as a crime under this Code or would be a crime if committed the territory of Ukraine. This means that if any of the crimes contemplated by the Rome Statute of the International Criminal Court is not recognized as a criminal offense under the current Criminal Code of Ukraine, then the sentence given by the consequences of its consideration will not be enforceable in the territory of Ukraine, even if the International Criminal Court accepts the decision to condemn the citizen of Ukraine. In the context of the ongoing conflict in eastern Ukraine, the harmonization of criminal law with the relevant provisions of the Rome Statute of the International Criminal Court is of particular importance.

The article also analyzes bills aimed at harmonizing national legislation with the provisions of international humanitarian law, including those of the Rome Statute of the International Criminal Court. As a result of such analysis, it was concluded that these bills are not complex in nature and will not regulate all areas in which the provisions of this Statute may be implemented. In this regard, it is emphasized that the ratification of the Rome Statute of the International Criminal Court must be uniquely complex and be accompanied by appropriate changes to the criminal, criminal procedural and criminal law laws that have been developed during this time by scholars, representatives of public organizations and subjects of legislative initiative.

Key words: international humanitarian law, Rome Statute of the International Criminal Court; international crimes, genocide crimes, crimes against humanity, war crimes, crimes of aggression. 